\title{
Incorporation of $\boldsymbol{N}$-Fluoroacetyl-D-glucosamine into Hyaluronate by Rabbit Tracheal Explants in Organ Culture
}

\author{
By David J. WINTERBOURNE, Robert J. BARNABY, Paul W. KENT and Nasi MIAN \\ Glycoprotein Research Unit, Science Laboratories, South Road, University of Durham, \\ Durham DH1 3LE, U.K.
}

(Received 20 February 1979)

\begin{abstract}
1. Incubation of rabbit tracheal explants with $N-\left[{ }^{3} \mathrm{H}\right]$ acetyl-D-glucosamine and $N$-acetyl$\mathrm{D}-\left[1-{ }^{14} \mathrm{C}\right] \mathrm{glucosamine}$ led to labelling of a number of soluble macromolecular products separable from the medium, after papain digestion, by ion-exchange chromatography. 2. With $N$-acetyl-D-[1-14 C]glucosamine in the incubation medium, a neutral glycoprotein, two acidic glycoprotein fractions, hyaluronic acid and a glycosaminoglycan fraction were obtained and all were radioactively labelled. Similar labelling occurred with $\mathrm{N}$ fluoroacetyl-D-[1-14 C]glucosamine or $N$-fluoro $\left[{ }^{3} \mathrm{H}\right]$ acetylglucosamine as precursor. 3 . Maximal labelling was obtained at $96 \mathrm{~h}$ after incubation of cultures. $\mathrm{N}$-Fluoroacetylglucosamine under these conditions was incorporated into hyaluronate less efficiently than $N$-acetylglucosamine. 4 . With $N$-fluoroacetyl-D- $\left[1-{ }^{14} \mathrm{C}\right]$ glucosamine as precursor, a hyaluronate component was separated that on enzymic degradation by glycosidases (hyaluronidase, $\beta$-glucuronidase and $N$-acetyl- $\beta$-hexosaminidase) yielded a ${ }^{14} \mathrm{C}$-labelled oligosaccharide fraction together with $\mathrm{N}$-acetyl-D-[1-14 C]glucosamine and $\mathrm{N}$-fluoroacetyl-D-[1-14 C]glucosamine, consistent with some exchange of $\mathrm{N}$-acetyl groups having occurred. 5. The results on enzymic degradation of labelled macromolecules by glycosidases suggest that the presence of incorporated $N$-fluoroacetyl side chains may render the hyaluronate analogue more resistant to hyaluronidase.
\end{abstract}

The totality of potential biological information in a protein structure is not fully defined by the amino acid sequence alone and an additional hierarchy of information can be envisaged by post-polymerization structural modifications. Such modifications include phosphorylation, sulphation and in particular glycosylation, resulting in additional information, known to contribute crucially to features of biological recognition. It is therefore of interest to explore specific means by which intervention in the processes of protein glycosylation can be achieved with a view to modifying the final information content without disturbance of the general metabolism of the cells.

The deoxyfluoromonosaccharides (reviewed by Kent, 1972; Foster \& Westwood, 1973) offer a way of exploring the hypothesis in mammalian cells. Existing evidence demonstrates that a variety of these sugars are readily transportable by mammalian cells (Barnett, 1972), where they can undergo phosphorylation and conversion into nucleotide sugar phosphates (Taylor, 1972; Schultz \& Mora, 1975). In mammalian systems, so far, there is no evidence of metabolic breakdown of these fluorosugars into toxic

Abbreviations used: GlcNAcF, $N$-fluoroacetylglucosamine; GlcNAc, $N$-acetylglucosamine. products as was at one time anticipated, though in some cases a limited oxidation and defluorination and in others reduction to hexitols has been observed (Kent \& Wright, 1972).

A fluoro-analogue of GlcNAc, capable of occupying the same binding sites as GlcNAc in the active centres of lysozyme (Butchard et al., 1972), was first reported to influence glycoprotein biosynthesis in fibroblast cell lines (Kent \& Mora, 1973), after exploratory studies by Daniels (1972). More recent studies have, however, indicated that the fluoroanalogues interfere competitively with the incorporation of unsubstituted sugars. $N$-Trifluoroacetyl-Dglucosamine had been reported to compete with $\left[{ }^{14} \mathrm{C}\right]$ glucosamine incorporation by $\mathrm{P} 288$ mouse lymphoma cells, apparently decreasing the cellular incorporation of glucosamine to $31 \%$ of the control value within $5 \mathrm{~h}$, but having no effect on the incorporation of $\left[{ }^{3} \mathrm{H}\right]$ leucine by the cells (Bernacki et al., 1977). Similarly, 2-fluoro-analogues of 2-deoxy-Dglucose and 2-deoxy-D-mannose had been found to behave as potent inhibitors in the synthesis of infectious Semliki forest and fowl plague viruses in chickembryo cells and of pseudorabies virus in rabbit kidney cells (Schmidt et al., 1976, 1978). The recently synthesized 2-deoxy-2-fluoro-L-fucose and its effect on glycoprotein-synthesizing cells is important in 
general metabolic turnover (Winterbourne et al., 1979).

In view of the structural complexity of glycoproteins and the difficulty in isolating them in a pure form, it was decided to investigate the incorporation of a fluoro-sugar into hyaluronate, which has a simple and well defined structure. With the availability of a biosynthetic system in the form of tracheal explants in organ culture (Gallagher \& Kent, 1975), the present studies have been carried out to investigate the influence of fluoro-substitution in the side chain in GlcNAc on its incorporation into hyaluronate.

A preliminary communication of some of these results has been reported (Kent \& Winterbourne, 1977).

\section{Materials and Methods}

\section{Synthesis of radioactively labelled GlcNAcF}

$\mathrm{N}$-Fluoroacetyl-D-[1-14 C]glucosamine. The method of Dwek et al. (1971) was adapted to prepare microquantities of the ring-labelled sugar.

Dicyclohexylcarbodi-imide $(120 \mathrm{mg})$ in pyridine $(8 \mathrm{ml})$ was added dropwise to a stirred solution of $\mathrm{D}-\left[1-{ }^{14} \mathrm{C}\right] \mathrm{glucosamine}$ hydrochloride $(150 \mu \mathrm{Ci}$, $0.25 \mathrm{mmol}$ ) and an excess of sodium fluoroacetate $(0.6 \mathrm{mmol})$ in water $(2 \mathrm{ml})$. After being continuously stirred at room temperature $\left(22^{\circ} \mathrm{C}\right)$ for $72 \mathrm{~h}$, the solution was diluted with $25 \mathrm{ml}$ of water, extracted with chloroform $(25 \mathrm{ml})$ and then with diethyl ether $(2 \times 25 \mathrm{ml})$. After concentration to about $1 \mathrm{ml}$, the aqueous solution was passed successively through two miniature ion-exchange columns $(1.5 \mathrm{~cm} \times 6 \mathrm{~cm})$. The first contained Dowex 50W (X8;200-400 mesh, $\mathrm{H}^{+}$form; Sigma Chemical Co., London SW6, U.K.) and the second Dowex $2\left(\mathrm{X} 8 ; 200-400\right.$ mesh, $\mathrm{HCO}_{3}{ }^{-}$ form; Sigma). The eluate was concentrated and the labelled sugar was purified several times by preparative paper chromatography on Whatman $3 \mathrm{MM}$ with the upper phase of butanol/ethanol/water $(4: 1: 5$, by vol.) as solvent.

The product $(29 \mu \mathrm{Ci})$ had a specific radioactivity of $300 \mu \mathrm{Ci} / \mathrm{mmol}$ (yield $32 \%$ by wt.). Of the ${ }^{14} \mathrm{C}$ radioactivity $99.9 \%$ resided in the finally purified $N$ fluoroacetyl-D-[1-14 C]glucosamine.

$\mathrm{N}$-Fluoro $\left[{ }^{3} \mathrm{H}\right]$ acetyl-D-glucosamine. Twice-recrystallized sodium fluoroacetate was tritiated by catalytic exchange in an aqueous medium at The Radiochemical Centre, Amersham, Bucks., U.K. Radioactively labelled sodium fluoroacetate, as received, had a specific radioactivity of approx. $250 \mathrm{mCi} / \mathrm{mmol}$. Of this, $8 \mathrm{mCi}$ was added to twice-recrystallized sodium fluoroacetate $(0.6 \mathrm{mmol})$ and co-recrystallized in ethanol. The resulting purified material $(2 \mathrm{mCi}$, $0.34 \mathrm{mmol}$ ) was added to an excess of glucosamine hydrochloride $(0.5 \mathrm{mmol})$ in $2 \mathrm{ml}$ of water and as before dicyclohexylcarbodi-imide $(120 \mathrm{mg})$ in pyridine $(8 \mathrm{ml})$ was added, while stirring continuously.
The reaction was allowed to proceed for six days at $20^{\circ} \mathrm{C}$ after which the solution was extracted and deionized as before. Purification was achieved by repeated preparative paper chromatography as described above. The solution of the tritiated products was passed through a Millipore filter $(0.22 \mu \mathrm{m})$ to remove traces of insoluble material. The solution was then freeze-dried giving a colourless solid $(215 \mu \mathrm{Ci}, 33 \mathrm{mg}$ yield, $39 \%$ by wt.) having a specific radioactivity of $1.5 \mathrm{mCi} / \mathrm{mmol}$. Of the ${ }^{3} \mathrm{H}$ radioactivity $99.9 \%$ resided in the finally purified $N$-fluoro$\left[{ }^{3} \mathrm{H}\right]$ acetyl-D-glucosamine.

$N$-Acetyl $\left[{ }^{3} \mathrm{H}\right]$ glucosamine. $\quad N$-Acetyl-D $\left[1-{ }^{3} \mathrm{H}\right]-$ glucosamine (sp. radioactivity $3-10 \mathrm{Ci} / \mathrm{mmol}$ ) was obtained from The Radiochemical Centre.

\section{Animals and materials}

Medium 199 and $\mathrm{NaHCO}_{3}$ were obtained from Wellcome Reagents, Beckenham, Kent, U.K. Gentamicin reagent solution was obtained from Essex Chemie A.-G., Lucerne, Switzerland. Fungizone was obtained from Squibb and Son, New York, NY, U.S.A. and penicillin and streptomycin, which were supplied in a single preparation called Crystamycin, were from Glaxo, Greenford, Middlesex, U.K. Rabbits were supplied by Hylyne Farms, Northwich, Cheshire, U.K.

Hyaluronidase (type VI, from bovine testis) and $\beta$-glucuronidase (type B-10, from bovine liver) were purchased from Sigma (London) Chemical Co., Kingston upon Thames, Surrey, U.K. $N$-Acetyl- $\beta$ D-glucosaminidase (from bovine kidney) was obtained from Boehringer. One unit of hyaluronidase (EC 3.2.1.35) is defined as the activity contained in $100 \mu \mathrm{g}$ of the international standard preparation, and 1 unit of $\beta$-glucuronidase (EC 3.2.1.31) and $N$-acetyl- $\beta$-Dglucosaminidase (EC 3.2.1.30) is defined as the enzyme activity capable of hydrolysing $1 \mu \mathrm{mol}$ of $p$-nitrophenyl $\beta$-D-glucuronide and $p$-nitrophenyl $N$-acetyl$\beta$-D-glucosaminide $/$ min at $37^{\circ} \mathrm{C}$ respectively.

\section{Organ culture of rabbit trachea explants}

This was as described by Gallagher \& Kent (1975).

Male rabbits $(2.5 \mathrm{~kg})$ were killed by intravenous injection $(60 \mathrm{mg} / \mathrm{kg}$ body wt. via an ear vein) of sodium pentobarbitone (Sagatal; May and Baker, Dagenham, Essex, U.K.).

The trachea was exposed and dissected immediately and placed in dissection medium (Gallagher \& Kent, 1975) maintained at $37^{\circ} \mathrm{C}$. Under sterile conditions, each excised trachea was cleared of any extraneous material and washed several times in warm dissection medium. The trachea was cut longitudinally into two parts and then each part was cut laterally into five further pieces giving 10 tracheal segments, each approximately $0.5 \mathrm{~cm}^{2}$ in size. All the segments used in each experiment were pooled. Two segments with epithelial surface facing upwards were placed on the 
incised surface of each of a series of plastic Petri dishes. Culture medium $(5 \mathrm{ml})$ containing known concentrations of GlcNAc and/or GlcNAcF was prepared for each dish. The sugar solutions were sterilized before addition to the culture medium by filtration through Millipore filters. Usually five Petri dishes were incubated with medium containing GlcNAcF and five for GlcNAc. Explants were maintained in an atmosphere of $\mathrm{O}_{2} / \mathrm{CO}_{2}(19: 1, \mathrm{v} / \mathrm{v})$ in single-strength medium 199 containing the following additions: $0.22 \%$ $\mathrm{NaHCO}_{3}, 50 \mu \mathrm{g}$ of gentamicin/ml, 100 units of penicillin $/ \mathrm{ml}, 100 \mu \mathrm{g}$ of streptomycin $/ \mathrm{ml}, 2.5 \mu \mathrm{g}$ of fungizone $/ \mathrm{ml}$, for up to 10 days, at which point the ciliary activity began to diminish.

\section{Single-label experiments}

The tracheal segments were kept for $24 \mathrm{~h}$ at $37^{\circ} \mathrm{C}$ in culture medium during which time most serum components had passed into the solution. This was replaced by fresh media containing $N$-acetyl-D$\left[1-{ }^{14} \mathrm{C}\right]$ glucosamine $(0.5-0.1 \mu \mathrm{Ci} / \mathrm{ml})$ or $N$-fluoroacetyl-D-[1- $\left.{ }^{14} \mathrm{C}\right]$ glucosamine $(0.5 \mu \mathrm{Ci} / \mathrm{ml})$ or $N$ fluoro $\left[{ }^{3} \mathrm{H}\right]$ acetyl-D-glucosamine $(0.2 \mu \mathrm{Ci} / \mathrm{ml}$ in the appropriate dishes. The concentration of GlcNAc or GlcNAcF in the media was $0.1 \mathrm{~mm}$ throughout the incubation. The medium was changed after a further 2 day interval and towards the end of the experiment exchanged for a solution containing unlabelled precursor to 'chase' labelled secretions.

Spent medium was removed by the use of a sterile Pasteur pipette. Each segment was rinsed thoroughly with the corresponding medium to remove adhering mucus. The medium collected after different incubation periods was kept separately. The gelatinous mucus material present in the samples was separated by centrifugation at $4000 \mathrm{~g}$ for $15 \mathrm{~min}$ and after several washings with medium was stored at $-20^{\circ} \mathrm{C}$. Finally at the end of each experiment, the tracheal segments were weighed and stored at $-20 \mathrm{C}$ for histological investigation.

The spent media containing soluble secreted fractions were exhaustively dialysed against water containing $\mathrm{NaN}_{3}(0.02 \%, \mathrm{w} / \mathrm{v})$, concentrated by rotary evaporation at $35^{\circ} \mathrm{C}$ for further fractionation and analysis.

\section{Double-label experiments}

In experiments with $N$-acetyl $\left[{ }^{3} \mathrm{H}\right]$ glucosamine and

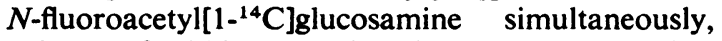
cultures of rabbit tracheal explants were prepared as described previously. Tissue from five female Chinchilla rabbits were pooled and eight segments were made from each trachea. After $24 \mathrm{~h}$ incubation, the culture medium was replaced to include $N$-acetyl$\left[{ }^{3} \mathrm{H}\right]$ glucosamine and $N$-fluoroacetyl $\left[1-{ }^{14} \mathrm{C}\right]$ glucosamine (each $0.3 \mu \mathrm{Ci} / \mathrm{ml}$ ).

After a further $48 \mathrm{~h}$ incubation, the medium was replaced by fresh medium with the same isotopically labelled metabolites and incubation continued for a further $48 \mathrm{~h}$. At the termination of the experiment tissue specimens still exhibited vigorous ciliary motion. The spent media collected after $48 \mathrm{~h}$ and $96 \mathrm{~h}$ were separately freed from gelatinous mucus by centrifugation at $4000 \mathrm{~g}$ for $15 \mathrm{~min}$ and washed several times with the medium. The supernatants containing soluble mucus were exhaustively dialysed against water containing $\mathrm{NaN}_{3}(0.02 \%, \mathrm{w} / \mathrm{v})$, and concentrated by rotary evaporation at $35^{\circ} \mathrm{C}$.

\section{Papain digestion}

Freeze-dried samples of tracheal secretions (1$5 \mathrm{mg} / \mathrm{ml}$ ) were suspended in $0.1 \mathrm{M}$-sodium citrate buffer (pH5.6) containing $1 \mathrm{M}-\mathrm{NaCl}, 5 \mathrm{~mm}-\mathrm{EDTA}$, $1 \mathrm{~mm}$-cysteine and crystalline papain $(0.5 \mathrm{mg} / \mathrm{ml}$; Sigma). Incubation was carried out at $60^{\circ} \mathrm{C}$ for $4 \mathrm{~h}$, when further papain $(0.2 \mathrm{mg} / \mathrm{ml})$ was added and kept at $60^{\circ} \mathrm{C}(20 \mathrm{~h})$. After cooling, protein was precipitated by the addition of trichloroacetic acid $(90 \%$, $w / v)$ to a final concentration of $10 \%(w / v)$ and left at $4{ }^{\circ} \mathrm{C}$ for $4 \mathrm{~h}$. The precipitate was removed by centrifugation, washed with $10 \%$ trichloroacetic acid, recentrifuged and the supernatant was pooled, dialysed against water and concentrated by rotary evaporation.

\section{Ion-exchange chromatography}

In previous experiments papain-digested samples of double-labelled tracheal secretions were fractionated on a DEAE-cellulose column $(5 \mathrm{~cm} \times 1.2 \mathrm{~cm})$ equilibrated with $10 \mathrm{~mm}-\mathrm{Tris} / \mathrm{HCl}$ buffer, $\mathrm{pH} 8.0$. The column was eluted with an $\mathrm{NaCl}$ linear gradient $(0$ to $0.75 \mathrm{M})$ in the same buffer and $3 \mathrm{ml}$ fractions were collected and ${ }^{14} \mathrm{C}$ and ${ }^{3} \mathrm{H}$ radioactivity were counted. Separated peaks were concentrated and dialysed against water and freeze-dried.

Papain-digested samples of tracheal secretions from single-label experiments were initially dialysed against $20 \mathrm{~mm}-\mathrm{Na}_{2} \mathrm{HPO}_{4} / \mathrm{NaH}_{2} \mathrm{PO}_{4}$ buffer, pH 7.2, containing $10 \mathrm{~mm}-\mathrm{NaCl}$ and $6 \mathrm{M}$-urea and fractionated on a DEAE-cellulose column $(5 \mathrm{~cm} \times 1.2 \mathrm{~cm})$ equilibrated with the same buffer. The column was first eluted with $15 \mathrm{ml}$ of the above buffer and then with a linear gradient of $0.01 \mathrm{M}-$ to $0.4 \mathrm{M}-\mathrm{NaCl}$ in a total volume of $100 \mathrm{ml}$ made up in the same buffer. Fractions of $3 \mathrm{ml}$ in volume were collected at a flow rate of $15 \mathrm{ml} / \mathrm{h}$. Portions were taken from each fraction and the radioactivity was measured in $5 \mathrm{ml}$ of NE260 scintillation fluid (Nuclear Enterprises, Edinburgh, Scotland, U.K.). Separated peaks were concentrated by rotary evaporation at $30^{\circ} \mathrm{C}$ and dialysed against $20 \mathrm{~mm}-\mathrm{Na}_{2} \mathrm{HPO}_{4} / \mathrm{NaH}_{2} \mathrm{PO}_{4}$ buffer, pH 7.2, containing $10 \mathrm{~mm}-\mathrm{NaCl}$ and $6 \mathrm{M}$-urea. The dialysed samples were fractionated again on a DEAEcellulose column under the same conditions but using a stepwise elution. Finally, separated compo-

Vol. 182 
nents were exhaustively dialysed against water and concentrated either by rotary evaporation or by freeze-drying.

\section{Cellulose acetate electrophoresis}

Column fractions and chromatographically separated components of tracheal secretions were analysed by zonal electrophoresis on cellulose acetate strips in $0.8 \mathrm{M}$-sodium barbitone/barbituric acid buffer $(\mathrm{pH} 8.6)$ at $250 \mathrm{~V}$ for $30 \mathrm{~min}$. The strips were fixed in $1 \%(\mathrm{w} / \mathrm{v})$ acetic acid and/or stained with periodate/Schiff reagent. Unstained strips were cut into $0.5 \mathrm{~cm}$ segments and counted in $5 \mathrm{ml}$ of NE260 scintillation fiuid.

\section{G.l.c.}

The carbohydrate composition of freeze-dried samples was analysed in this laboratory by Dr. Maria C. Dillon after methanolysis, by the method of Clamp et al. (1971).

\section{Digestion of hyaluronate fractions by a mixture of glycosidases}

Fractions of radioactively labelled hyaluronate purified by ion-exchange chromatography were subjected to degradation by a mixture of hyaluronidase (100 units), $\beta$-glucuronidase (200 units) and $N$-acetyl$\beta$-D-glucosaminidase $(0.2$ unit $)$ in $0.1 \mathrm{M}$-sodium acetate/acetic acid buffer, pH5.0, containing $0.4 \mathrm{M}$ $\left(\mathrm{NH}_{4}\right)_{2} \mathrm{SO}_{4}$ and $0.15 \mathrm{M}-\mathrm{NaCl}$ at $37^{\circ} \mathrm{C}$ in a total volume of $0.2 \mathrm{ml}$. The amount of each glycosidase was doubled and trebled after 5 and $24 \mathrm{~h}$ respectively and portions of the digest were taken at each stage for chromatographic analysis. The digestion was carried out for a maximun period of $12 \mathrm{~h}$. Digested samples were applied to Whatman no. 1 chromatography paper and run in pyridine/ethyl acetate/water, (2:8:1, by vol.) as solvent for $20 \mathrm{~h}$ at $22^{\circ} \mathrm{C}$. In this solvent, GlcNAcF $\left(R_{F} 0.27\right)$ and GlcNAc $\left(R_{F} 0.15\right)$ were clearly separated. Strips $(1 \mathrm{~cm})$ were cut and counted in $5 \mathrm{ml}$ of NE260 scintillation fluid.

\section{Presentation of the incorporation data}

The incorporation of a radioactive precursor into hyaluronate is expressed as a percentage of the initial total amount of radioactive precursor used or of its specific radioactivity as stated for individual experiments.

\section{Results}

Incorporation of $\mathrm{N}$-acetylglucosamine and its fuoroanalogues into tracheal secretion

$N$-Acetyl-D- $\left[1-{ }^{14} \mathrm{C}\right]$ glucosamine, used as precursor, was incorporated into all four principal proteinpolysaccharide products isolated from the culture fluid (Fig. 1). The use of $N$-fluoroacetyl $\left[1-{ }^{14} \mathrm{C}\right]$ glucosamine and $N$-fluoro $\left[{ }^{3} \mathrm{H}\right]$ acetyl-D-glucosamine

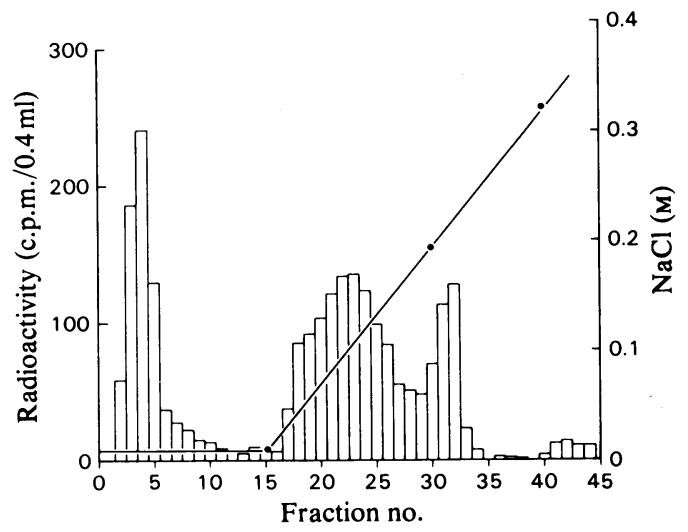

Fig. 1. Ion-exchange chromatography of soluble secreted products from rabbit tracheal explants incubated for $144 \mathrm{~h}$ with $\mathrm{N}$-acetyl-D-[1-14 $\mathrm{C}] \mathrm{glucosamine}$

Papain-digested samples of tracheal secretion were dialysed against $20 \mathrm{~mm}-\mathrm{Na}_{2} \mathrm{HPO}_{4} / \mathrm{NaH}_{2} \mathrm{PO}_{4}$ buffer $\mathrm{pH} 7.2$, containing $10 \mathrm{~mm}-\mathrm{NaCl}$ and $6 \mathrm{M}$-urea and were then fractionated on a DEAE-cellulose column $(5 \mathrm{~cm} \times 1.2 \mathrm{~cm})$ equilibrated with the same buffer. The column was eluted first with $15 \mathrm{ml}$ of the above buffer followed by a linear gradient of $0.01 \mathrm{M}$ - to $0.4 \mathrm{M}-\mathrm{NaCl}$ in a total volume of $100 \mathrm{ml}$ in the same buffer. The fractions $(3 \mathrm{ml})$ were collected at a flow rate of $15 \mathrm{ml} / \mathrm{h}$. Neutral glycoprotein was fractions 1-11 inclusive, acidic glycoproteins were fractions 16-29 inclusive and hyaluronate was fractions 30-34 inclusive. The sulphated glycoaminoglycans were in fractions 40-45. Symbol: $\bullet,[\mathrm{NaCl}]$.

as precursors showed no qualitative differences in the incorporation profiles when compared with that of $\mathrm{N}$-acetyl-D-[1-14 C]glucosamine. A comparison of the amounts of all three precursors present in papaindigested secreted products is shown in Table 1. It was observed that GICNAcF-labelled products consistently required a slightly higher molar concentration of $\mathrm{NaCl}$ in the gradient for their displacement in DEAE-cellulose chromatography. The hyaluronate component, though quantitatively minor was nevertheless substantially labelled, $16.8 \%$ incorporation from the $N$-fluoroacetyl-D-[1-14 C]glucosamine precursor compared with $10.7 \%$ from the $N$-fluoro $\left[{ }^{3} \mathrm{H}\right]$ acetyl-D-glucosamine precursor. Double labelling experiments with $N$-fluoroacetyl-D- $\left[1-{ }^{14} \mathrm{C}\right]$ glucosamine and $N$-acetyl-D- $\left[{ }^{3} \mathrm{H}\right]$ glucosamine in $96 \mathrm{~h}$ incubations showed an apparent enrichment of hyaluronate fraction in ${ }^{3} \mathrm{H}$ compared with ${ }^{14} \mathrm{C}\left({ }^{14} \mathrm{C} /{ }^{3} \mathrm{H}\right.$ ratio, $0.088: 1)$ since the ${ }^{14} \mathrm{C} /{ }^{3} \mathrm{H}$ ratio originally present in the culture medium was 0.117:1 (Table 2). The isotopic yields of the hyaluronate were $2.3 \%$ with respect to ${ }^{14} \mathrm{C}$ ( $\mathrm{N}$-fluoroacetylglucosamine) and $5.7 \%$ with respect to the ${ }^{3} \mathrm{H}$-labelled fluorine-free compound (GlcNAc). In these experiments, both 
Table 1. Distribution of ${ }^{14} \mathrm{C}$ and ${ }^{3} \mathrm{H}$ radioactivity in papain-digested soluble secreted products of rabbit tracheal explants Pooled tissue from three animals was incubated for $240 \mathrm{~h}$ in medium $(100 \mathrm{ml})$ containing labelled amino-sugar (single label). Tracheal secretions were exhaustively dialysed against water and freeze-dried and their papain-digested products were separated on a DEAE-cellulose column $(5 \mathrm{~cm} \times 1.2 \mathrm{~cm})$ equilibrated with $20 \mathrm{mM}-\mathrm{Na}_{2} \mathrm{HPO}_{4} / \mathrm{NaH}_{2} \mathrm{PO}_{4}$ buffer, pH 7.2, containing $6 \mathrm{M}$-urea. The column was eluted with a linear gradient of 0 to $0.4 \mathrm{M}-\mathrm{NaCl}$ in the same buffer. Separated products were identified as described in the text. No measurements were made for the glycosaminoglycan fraction eluted after the $\mathrm{NaCl}$ gradient concentration reached $0.3 \mathrm{M}$.

Radioactivity in chromatographically isolated products $(\%)$

\begin{tabular}{|c|c|c|c|c|c|}
\hline \multirow[b]{3}{*}{ Secreted products } & \multirow{2}{*}{\multicolumn{2}{|c|}{$\begin{array}{c}\mathrm{NaCl} \text { concentration of } \\
\text { gradient }(M)\end{array}$}} & \multicolumn{3}{|c|}{ isolated products $(\%)$} \\
\hline & & & \multirow{2}{*}{$\begin{array}{c}{ }^{14} \mathrm{C} \text {-labelled } \\
\text { GlcNAc } \\
(0.1 \mu \mathrm{Ci} / \mathrm{ml} \dagger)\end{array}$} & \multirow{2}{*}{$\begin{array}{c}{ }^{14} \mathrm{C} \text {-labelled } \\
\text { GlcNAcF } \\
(0.05 \mu \mathrm{Ci} / \mathrm{ml} \dagger)\end{array}$} & \multirow{2}{*}{$\begin{array}{c}{ }^{3} \mathrm{H} \text {-labelled } \\
\text { GlcNAcF } \\
(0.25 \mu \mathrm{Ci} / \mathrm{ml}+)\end{array}$} \\
\hline & GlcNAc & GlcNAcF* & & & \\
\hline Neutral glycoprotein & $0-0.01$ & $0-0.01$ & 31.4 & 32.1 & 32.3 \\
\hline $\begin{array}{l}\text { Acidic glycoprotein I } \\
\text { Acidic glycoprotein II }\end{array}$ & $\begin{array}{l}0.05 \\
0.085\end{array}$ & $\begin{array}{l}0.055 \\
0.10\end{array}$ & 57.0 & 51.1 & 57.0 \\
\hline Hyaluronic acid & 0.19 & 0.22 & 11.6 & 16.8 & 10.7 \\
\hline
\end{tabular}

* ${ }^{14} \mathrm{C}$ - or ${ }^{3} \mathrm{H}$-labelled sugar.

$\dagger$ Initial value in medium.

Table 2. Ratio of ${ }^{14} \mathrm{C} /{ }^{3} \mathrm{H}$ labelling of papain-digested secretions of rabbit tracheal explants incubated simultaneously with $N$-fluoroacetyl-D-[1-14 C $]$ glucosamine and $\mathrm{N}$-acetyl-D- $\left[{ }^{3} \mathrm{H}\right] \mathrm{g} /$ ucosamine

Incubations were carried out for $96 \mathrm{~h}$ with pooled tissues; products were papain-digested and separated on DEAE-cellulose columns as described in Table 1.

$\begin{array}{cccc}\text { Secreted } & \begin{array}{c}\text { Effluent } \\ \text { volume } \\ \text { (ml) }\end{array} & \begin{array}{c}\mathrm{NaCl} \text { concen- } \\ \text { tration of } \\ \text { eluting } \\ \text { gradient }(\mathrm{M})\end{array} & \begin{array}{c}{ }^{14} \mathrm{C} /{ }^{3} \mathrm{H} \text { in } \\ \text { isolated } \\ \text { product* }\end{array} \\ \begin{array}{c}\text { products } \\ \begin{array}{c}\text { Neutral glyco- } \\ \text { protein }\end{array}\end{array} & 4-17 & 0 & 0.037 \\ \begin{array}{c}\text { Acidic glyco- } \\ \text { protein I }\end{array} & 23-27 & 0.08 & 0.042 \\ \begin{array}{c}\text { Acidic glyco- } \\ \text { protein II }\end{array} & 28-34 & 0.10 & 0.047 \\ \begin{array}{c}\text { Hyaluronic } \\ \text { acid }\end{array} & 36,37 & 0.23 & 0.088 \\ \begin{array}{c}\text { Glycosamino- } \\ \text { glycan I }\end{array} & 41-45 & 0.45 & 0.07 \\ \begin{array}{c}\text { Glycosamino- } \\ \text { glycan II }\end{array} & 47-52 & 0.50 & 0.094\end{array}$

glycan II

* The ratio ${ }^{14} \mathrm{C} /{ }^{3} \mathrm{H}$ in the initial culture fluid was $0.117: 1$ The value was $0.044: 1$ for the papain-digested mixed products, before DEAE-cellulose fractionation.

isotopic precursors were present in all the secreted components separated chromatographically.

In view of the proximity of fractions eluted by ion-exchange chromatography, acidic glycoprotein fractions I and II (Fig. 1, fractions 11-29 inclusive) were refractionated on DEAE-cellulose column with an $\mathrm{NaCl}$ gradient, but using stepwise elution. The labelled glycoproteins were quantitatively recovered and the amount of hyaluronate as a contaminant was negligible (Fig. 2a). When the hyaluronate fraction (Fig. 1, fractions 30-34) was refractionated under similar chromatographic conditions, $95 \%$ of the label was recovered as hyaluronate (Fig. $2 b$ ). Zonal electrophoresis of this material on cellulose acetate showed a single component staining with Alcian Blue and having the same mobility as standard hyaluronate (BDH Chemicals, Poole, Dorset, U.K.). The hyaluronate fraction was clearly separated from added chondroitin sulphate on electrophoresis on cellulose acetate strips.

\section{Extent of incorporation of GlcNAc and its fuoro- analogues}

In studies on the amount of incorporation of GlcNAc and GlcNAcF into total macromolecular secreted products, it was found that $3.19 \%$ of ${ }^{14} \mathrm{C}$ radioactivity originating from $N$-acetyl-D- $\left[1-{ }^{14} \mathrm{C}\right]-$ glucosamine was present after the first $24 \mathrm{~h}$ period and $2.55 \%$ after the second such period of incubation.

The validity of the incorporation was further demonstrated by subsequent sequential 'chase' experiments with non-radioactive precursor present, with a 10 -fold decrease in the amount of ${ }^{14} \mathrm{C}$ radioactivity (originated from $\mathrm{N}$-acetyl-D-[1-14 $\mathrm{C}] \mathrm{glucos}$ amine) present in the total secretions (Table 3). In simultaneous experiments, labelling with $\mathrm{N}$-fluoroacetyl-D- $\left[1-{ }^{14} \mathrm{C}\right]$ glucosamine was $1.11 \% \quad(1.20 \%$, duplicate value) and $1.14 \%$ (1.53\%, duplicate) for two sequential periods of incubation each $24 \mathrm{~h}$. The corresponding labelling yield was $0.86 \%(1.24 \%$, duplicate) for $\mathrm{N}$-fluoro $\left[{ }^{3} \mathrm{H}\right]$ acetyl-D-glucosamine. Similarly in the case of fluoroacetyl analogues the amount of ${ }^{14} \mathrm{C}$ - or ${ }^{3} \mathrm{H}$-labelled material present in the secreted products was substantially diminished in 'chase' conditions, the decrease being less compared with that observed in the presence of unsubstituted GlcNAc (Table 3). 

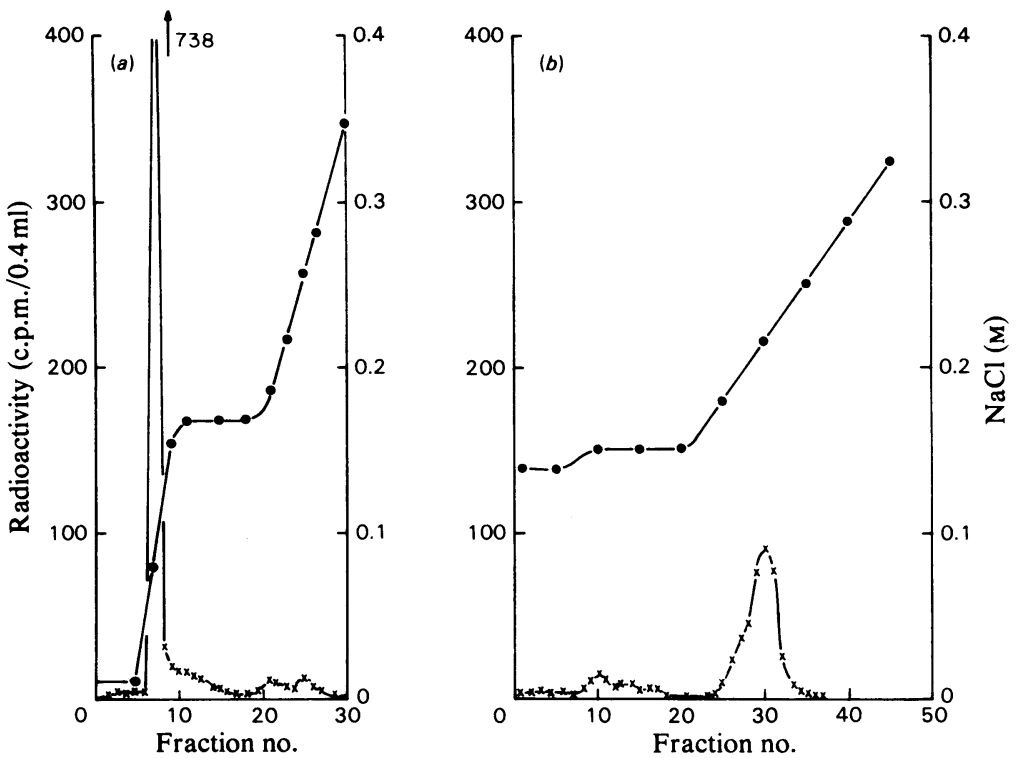

Fig. 2. Refractionation of acidic glycoprotein fractions I and II and hyaluronate from rabbit tracheal secretion on ion-exchange chromatography

Acidic glycoprotein fractions I and II and hyaluronate fractions collected from the first DEAE-cellulose column were concentrated. Acidic glycoprotein fractions were dialysed against $20 \mathrm{mM}-\mathrm{Na}_{2} \mathrm{HPO}_{4} / \mathrm{NaH}_{2} \mathrm{PO}_{4}$ buffer, $\mathrm{pH} 7.2$, containing $6 \mathrm{M}$-urea, and hyaluronate fractions were dialysed against $20 \mathrm{~mm}-\mathrm{Na}_{2} \mathrm{HPO}_{4} / \mathrm{NaH}_{2} \mathrm{PO}_{4}$ buffer, $\mathrm{pH} 7.2$, containing $0.17 \mathrm{M}$ $\mathrm{NaCl}$ and $6 \mathrm{M}$-urea. (a) Acidic glycoprotein fractions I and II were fractionated on a DEAE-cellulose column $(5 \mathrm{~cm} \times$ $1.2 \mathrm{~cm}$ ) equilibrated with $20 \mathrm{mM}-\mathrm{Na}_{2} \mathrm{HPO}_{4} / \mathrm{NaH}_{2} \mathrm{PO}_{4}$ buffer, $\mathrm{pH} 7.2$, containing $6 \mathrm{M}$-urea. The column was eluted with a linear gradient of 0 to $0.17 \mathrm{M}-\mathrm{NaCl}$ in the same buffer and fractions $(4 \mathrm{ml})$ were collected. $(b)$ Hyaluronate was fractionated on a DEAE-cellulose column $(5 \mathrm{~cm} \times 1.2 \mathrm{~cm})$ equilibrated with $20 \mathrm{~mm}-\mathrm{Na}_{2} \mathrm{HPO}_{4} / \mathrm{NaH}_{2} \mathrm{PO}_{4}$ buffer, pH 7.2 , containing $0.17 \mathrm{M}-\mathrm{NaCl}$ and $6 \mathrm{M}$-urea. The column was eluted with a linear gradient of $0.17 \mathrm{M}-$ to $0.4 \mathrm{M}-\mathrm{NaCl}$ in the same buffer and fractions $(4 \mathrm{ml})$ were collected. Symbols: $\bullet,[\mathrm{NaCl}] ; \times$, radioactivity.

Table 3. Labelling of total native soluble secretions of rabbit tracheal explants labelled by incubation with $N$-acetyl$\left[1-{ }^{14} \mathrm{C}\right]$ glucosamine, or $N$-fluoroacetyl-D- $\left[1-{ }^{14} \mathrm{C}\right]$ glucosamine or $N$-fluoro $\left[{ }^{3} \mathrm{H}\right]$ acetyl-D-glucosamine (single label experiments)

Incubations were carried out for $96 \mathrm{~h}$ with $40 \mathrm{ml}$ of culture fluid, in the presence of various labelled precursors. The medium was then exchanged with a solution of identical molar concentration of unlabelled precursor and incubation was continued for a further $48 \mathrm{~h}$. The spent media were dialysed exhaustively at $4^{\circ} \mathrm{C}$ before counting for radioactivity. Values are expressed as total radioactivity $(\mathrm{nCi})$ and as a percentage recovery of initial radioisotope present in the media.

Radioactive label in medium

\begin{tabular}{|c|c|c|c|c|c|c|c|c|c|}
\hline \multicolumn{4}{|c|}{ Expt. 1} & \multicolumn{6}{|c|}{ Expt. 2} \\
\hline \multicolumn{2}{|c|}{$\begin{array}{c}{ }^{14} \text { C-labelled } \\
\text { GlcNAc } \\
(825 \mathrm{nCi} ; 0.1 \mathrm{~mm})\end{array}$} & \multicolumn{2}{|c|}{$\begin{array}{c}{ }^{14} \text { C-labelled } \\
\text { GlcNAcF } \\
(972 \mathrm{nCi} ; 0.1 \mathrm{~mm})\end{array}$} & \multicolumn{2}{|c|}{$\begin{array}{c}{ }^{14} \text { C-labelled } \\
\text { GlcNAc } \\
(2.24 \mathrm{mCi} ; 0.1 \mathrm{~mm})\end{array}$} & \multicolumn{2}{|c|}{$\begin{array}{c}{ }^{14} \text { C-labelled } \\
\text { GlcNAcF } \\
(989 \mathrm{nCi} ; 0.1 \mathrm{~mm})\end{array}$} & \multicolumn{2}{|c|}{$\begin{array}{c}{ }^{3} \mathrm{H} \text {-labelled } \\
\text { GlcNAcF } \\
(3.345 \mathrm{mCi} ; 0.1 \mathrm{~mm}\end{array}$} \\
\hline$(\mathrm{nCi})$ & $(\%)$ & $(\mathrm{nCi})$ & $(\%)$ & $(\mathrm{nCi})$ & $(\%)$ & $(\mathrm{nCi})$ & $(\%)$ & $(\mathrm{nCi})$ & $(\%)$ \\
\hline $\begin{array}{r}27.4 \\
21.9 \\
2.9 \\
2.6\end{array}$ & $\begin{array}{l}3.19 \\
2.55\end{array}$ & $\begin{array}{c}10.81 \\
11.1 \\
4.1 \\
3.9\end{array}$ & $\begin{array}{l}1.11 \\
1.14\end{array}$ & $\begin{array}{r}73.6 \\
69.6 \\
22.6 \\
9.3\end{array}$ & $\begin{array}{l}3.29 \\
3.11\end{array}$ & $\begin{array}{l}11.97 \\
15.1\end{array}$ & $\begin{array}{l}1.20 \\
1.53\end{array}$ & $\begin{array}{l}28.8 \\
41.4\end{array}$ & $\begin{array}{l}0.86 \\
1.24\end{array}$ \\
\hline
\end{tabular}


Table 4. Time course of distribution of label into native soluble secretions of rabbit tracheal explants incubated with $N$ aceryl-D- $\left[1-{ }^{14} \mathrm{C}\right] \mathrm{g} /$ ucosamine or $\mathrm{N}$-fluoroacetyl-D-[1-14 C $]$ glucosamine

Incubations were carried out sequentially for three periods of $48 \mathrm{~h}$ with respective labelled precursors for the first two periods as in Table 2 (Expt. 2). In the third incubation period, unlabelled medium contained identical molar concentration of unlabelled precursors. Values are percentages of total radioactivity eluted from DEAE-cellulose fractionation of the mixed components.

Radioactivity ( $\%$ of total radioactivity eluted)

\begin{tabular}{|c|c|c|c|c|c|c|c|c|}
\hline \multirow{2}{*}{$\begin{array}{l}\text { Incu- } \\
\text { bation } \\
\text { period } \\
\text { (h) }\end{array}$} & \multirow{2}{*}{$\begin{array}{l}\text { Components } \\
\text { Labelled } \\
\text { precursor }\end{array}$} & \multirow{2}{*}{$\begin{array}{l}\cdots \\
\ldots\end{array}$} & \multicolumn{2}{|c|}{ Neutral glycoprotein } & \multicolumn{2}{|c|}{ Acidic glycoproteins } & \multicolumn{2}{|c|}{ Hyaluronate } \\
\hline & & & $\begin{array}{c}{ }^{14} \text { C-labelled } \\
\text { GlcNAc }\end{array}$ & $\begin{array}{c}{ }^{14} \text { C-labelled } \\
\text { GlcNAcF }\end{array}$ & $\begin{array}{c}{ }^{14} \mathrm{C} \text {-labelled } \\
\text { GlcNAc }\end{array}$ & $\begin{array}{c}{ }^{14} \mathrm{C} \text {-labelled } \\
\text { GlcNAcF }\end{array}$ & $\begin{array}{l}{ }^{14} \text { C-labelled } \\
\text { GlcNAc }\end{array}$ & $\begin{array}{c}{ }^{14} \mathrm{C} \text {-labelled } \\
\text { GlcNAcF }\end{array}$ \\
\hline $\begin{array}{c}0-48 \\
48-96 \\
96-144\end{array}$ & & & $\begin{array}{l}25.9 \\
30.5 \\
19.6\end{array}$ & $\begin{array}{l}20.0 \\
23.6 \\
29.4\end{array}$ & $\begin{array}{l}52.6 \\
44.5 \\
48.1\end{array}$ & $\begin{array}{l}57.5 \\
47.0 \\
40.9\end{array}$ & $\begin{array}{l}21.4 \\
25.0 \\
32.3\end{array}$ & $\begin{array}{l}22.5 \\
29.4 \\
29.3\end{array}$ \\
\hline
\end{tabular}

Table $5 .{ }^{14} \mathrm{C}$ or ${ }^{3} \mathrm{H}$ radioactivity in the refractionated hyaluronate component, after papain digestion, from rabbit tracheal explants incubated in the presence of $N$ acetyl-D- $\left[{ }^{14} \mathrm{C}\right]$ glucosamine, $N$-fluoroacetyl-D- $\left[1-{ }^{14} \mathrm{C}\right]$ glucosamine or $\mathrm{N}$-fluoro $\left[{ }^{3} \mathrm{H}\right]$ acety/-D-glucosamine

Incubations $(48 \mathrm{~h})$ were carried out as described in Table 4. Values are expressed as \% of total radioactivity present originally in culture media.

\section{Radioactivity in medium}

\begin{tabular}{|c|c|c|c|c|c|c|c|}
\hline \multirow[t]{2}{*}{$\begin{array}{l}\text { Labelled } \\
\text { precursor }\end{array}$} & $\cdots$ & \multicolumn{2}{|c|}{$\begin{array}{c}{ }^{14} \text { C-labelled } \\
\text { GlcNAc }\end{array}$} & \multicolumn{2}{|c|}{$\begin{array}{l}{ }^{14} \text { C-labelled } \\
\text { GlcNAcF }\end{array}$} & \multicolumn{2}{|c|}{$\begin{array}{l}{ }^{3} \mathrm{H} \text {-labelled } \\
\text { GicNAcF }\end{array}$} \\
\hline & & $(\mathrm{nCi})$ & $(\%)$ & $(\mathrm{nCi})$ & $(\%)$ & $(\mathrm{nCi})$ & $(\%)$ \\
\hline $\begin{array}{l}\text { Exp. } 1 . \\
\text { Exp. } 2 .\end{array}$ & & $\begin{array}{l}2.50 \\
5.68\end{array}$ & $\begin{array}{l}0.15 \\
0.13\end{array}$ & $\begin{array}{l}3.09 \\
3.14\end{array}$ & $\begin{array}{l}0.16 \\
0.16\end{array}$ & $\overline{5.36}$ & $0 . \overline{08}$ \\
\hline
\end{tabular}

Time course of distribution of labelled $\mathrm{N}$-acetylglucosamine and its fuoro-analogues into native soluble secretions of rabbit tracheal explants

Over a period of $144 \mathrm{~h}$, the labelling of the neutral glycoprotein fraction (Fig. 1, fractions 1-11 inclusive) with $\mathrm{N}$-acetyl-D-[1- $\left.{ }^{14} \mathrm{C}\right]$ glucosamine decreased from $25.9 \%$ (first $48 \mathrm{~h}$ ) to $19.6 \% 96$ to $144 \mathrm{~h}$ period of incubation). In contrast, the uptake of $\mathrm{N}$-fluoroacetyl-D- $\left[1-{ }^{14} \mathrm{C}\right] \mathrm{g}$ lucosamine as precursor into this fraction increased from $20.0 \%$ to $29.4 \%$ in the corresponding periods. Among the acidic glycoprotein fractions, the rate of labelling of the major radioactive product with either $N$-acetyl-D- $\left[1-{ }^{14} \mathrm{C}\right]$ glucosamine or $N$-fluoroacetyl-D-[1-14 C]glucosamine decreased in both cases over $144 \mathrm{~h}$ (Table 4$)$. In the same periods, the labelling of the hyaluronate increased from $21.4 \%$ (first $48 \mathrm{~h}$ ) to $32.3 \%$ (96-144h) with the ${ }^{14} \mathrm{C}$-labelled GlcNAc compared with an increase from $22.5 \%$ to $29.3 \%$ in the case of the ${ }^{14} \mathrm{C}$ labelled GlcNAcF. Further details of the labelled refractionated hyaluronate are given in Table 5.
Identification of radioactively labelled sugars in hyaluronate fractions

The purified hyaluronate (fractions 30-34, Fig. 2) containing ${ }^{14} \mathrm{C}$-labelled GlcNAc, ${ }^{14} \mathrm{C}$-labelled GlcNAcF or ${ }^{3} \mathrm{H}$-labelled GlcNAcF was digested by using a mixture of hyaluronidase, $\beta$-glucuronidase and $N$-acetyl- $\beta$-D-glucosaminidase. Digestion was carried out for 48,72 and $120 \mathrm{~h}$ and after each time interval the products were separated by paper chromatography.

Paper-chromatographic analysis of the products released by enzymic digestion $(120 \mathrm{~h})$ of hyaluronate labelled with ${ }^{14} \mathrm{C}$-labelled GIcNAc showed that $45.9 \%$ of the label was released as an oligosaccharide/disaccharide fraction $\left(R_{F} 0\right)$, whereas $54.1 \%$ was in the form of ${ }^{14} \mathrm{C}$-labelled GlcNAc $\left(R_{F} 0.15\right)$. Glucuronic acid was also readily detected colorimetrically, though this was of course unlabelled. Similar analysis of hyaluronate labelled with ${ }^{14} \mathrm{C}$ labelled GIcNAcF indicated that $74.6 \%$ of the label was released as an oligosaccharide/disaccharide fraction, $19.5 \%$ as ${ }^{14} \mathrm{C}$-labelled GlcNAc $\left(R_{F} 0.15\right)$ and $5.9 \%$ as ${ }^{14} \mathrm{C}$-labelled GlcNAcF $\left(R_{F} 0.27\right)$. In similar experiments where ${ }^{3} \mathrm{H}$-labelled GIcNAcF had been used as a precursor, $95.4 \%$ of the label was recovered in the oligosaccharide/disaccharide fraction $\left(R_{F} 0\right)$ and $4.6 \%$ as ${ }^{3} \mathrm{H}$-labelled GlcNAcF $\left(R_{F} 0.27\right)$. Unlabelled GlcNAc was also present, which was detected colorimetrically on the chromatograms (Table 6). In further experiments more extensive chromatographic separation of the enzymically digested products indicated the presence of a disaccharide component ( $N$-acetylhyalobiuronic acid) containing $3.1 \%$ as ${ }^{14} \mathrm{C}$-labelled GlcNAc and $2.3 \%$ as ${ }^{14} \mathrm{C}$-labelled GlcNAc and of a distinctive disaccharide component (believed to be $N$-fluoroacetylhyalobiuronic acid) only where GlcNAcF had been used as a precursor, and this represented $3.1 \%$ of the ${ }^{14} \mathrm{C}$ radioactivity incorporated into hyaluro-

Vol. 182 
Table 6. Distribution of ${ }^{14} \mathrm{C}$ and ${ }^{3} \mathrm{H}$ in products of mixed-glycosidase digestion of purified hyaluronate fraction obtained by incubation of rabbit tracheal explants with ${ }^{14} \mathrm{C}$-labelled GlcNAc or GlcNAcF $\left({ }^{14} \mathrm{C}\right.$ - or ${ }^{3} \mathrm{H}$-labelled)

Refractionated hyaluronate component, separated as described in the Materials and Methods section and in Tables 3 and 4 , was incubated with a mixture of hyaluronidase, $\beta$-glucuronidase and $N$-acetyl- $\beta$-D-hexosaminidase for 48,72 and $120 \mathrm{~h}$ respectively (for conditions see the Materials and Methods section.) Hydrolysis products were separated chromatographically on paper, located and counted for radioactivity. Values given for chromatographic components are radioactivity counts detected as a percentage of counts applied to the paper chromatogram.

\begin{tabular}{|c|c|c|c|c|c|c|c|c|c|c|}
\hline \multirow{3}{*}{$\begin{array}{l}\text { Chromatographic } \\
\text { component }\end{array}$} & \multirow{3}{*}{$\begin{array}{l}\text { Labelled precursor } \\
\text { used in incu- } \\
\text { bation }\end{array}$} & \multirow{3}{*}{$\begin{array}{l}\cdots \\
\ldots\end{array}$} & \multicolumn{8}{|c|}{ Radioactivity ( $\%$ of radioactivity applied to chromatogram) } \\
\hline & & & \multicolumn{3}{|c|}{$\begin{array}{l}{ }^{14} \text { C-labelled } \\
\text { GlcNAc }\end{array}$} & \multicolumn{3}{|c|}{$\begin{array}{l}{ }^{14} \text { C-labelled } \\
\text { GlcNAcF }\end{array}$} & \multicolumn{2}{|c|}{$\begin{array}{l}{ }^{3} \mathrm{H} \text {-labelled } \\
\text { GlcNAcF }\end{array}$} \\
\hline & & & 48 & 72 & 120 & 48 & 72 & 120 & 72 & 120 \\
\hline $\begin{array}{l}\text { igosaccharide }\left(R_{F} 0\right) \\
\text { cNAc }\left(R_{F} 0.15\right) \\
\text { cNAcF }\left(R_{F} 0.27\right)\end{array}$ & & & $\begin{array}{c}50.2 \\
49.8 \\
0\end{array}$ & $\begin{array}{c}38.9 \\
61.1 \\
0\end{array}$ & $\begin{array}{c}45.9 \\
54.1 \\
0\end{array}$ & $\begin{array}{l}63.0 \\
25.1 \\
11.9\end{array}$ & $\begin{array}{r}66.9 \\
26.5 \\
6.5\end{array}$ & $\begin{array}{r}74.6 \\
19.5 \\
5.9\end{array}$ & $\begin{array}{c}88.8 \\
0 \\
11.2\end{array}$ & $\begin{array}{c}95.4 \\
0 \\
4.6\end{array}$ \\
\hline
\end{tabular}

Table 7. Extended chromatographic separation of products of mixed glycosidase degradation of hyaluronate isotopically labelled from ${ }^{14} \mathrm{C}$-labelled GICNAcF or ${ }^{14} \mathrm{C}$-labelled GlcNAc

The enzymic hydrolysis was conducted for $48 \mathrm{~h}$, and the analysis was carried out as described in the Materials and Methods section. Hydrolysis products were separated chromatographically on paper by using pyridine/ethyl acetate/water $(2: 8: 1$, by vol.) as solvent. Values are expressed as a percentage of the counts applied to paper.

\begin{tabular}{|c|c|c|c|}
\hline \multirow{2}{*}{$\begin{array}{l}\text { Products } \\
\text { of } \\
\text { hydrolysis }\end{array}$} & \multirow[b]{2}{*}{ Precursor ... } & \multicolumn{2}{|c|}{ Radioactivity (\%) } \\
\hline & & $\begin{array}{c}{ }^{14} \mathrm{C}-\text { labelled } \\
\text { GlcNAcF }\end{array}$ & $\begin{array}{c}{ }^{14} \mathrm{C} \text {-labelled } \\
\text { GlcNAc }\end{array}$ \\
\hline $\begin{array}{l}\text { Oligosac- } \\
\text { charide } \\
\left(R_{F} 0\right)\end{array}$ & & 59.3 & 46.0 \\
\hline $\begin{array}{c}\text { Acetylhyalo- } \\
\text { biuronate }\end{array}$ & & 10.3 & 2.3 \\
\hline $\begin{array}{l}\text { Fluoroacetyl- } \\
\text { hyalur- } \\
\text { onate }\end{array}$ & & 3.1 & - \\
\hline GlcNAc & & 21.2 & 51.4 \\
\hline GlcNAcF & & 5.9 & - \\
\hline
\end{tabular}

nate from ${ }^{14} \mathrm{C}$-labelled GlcNAcF. The complete analysis is given in Table 7 .

\section{Discussion}

The identification of the hyaluronate fraction, obtained from the tracheal explants in the organ culture by its chemical analysis and its susceptibility to the action of hyaluronidase has been previously described (Gallagher \& Kent, 1975). These studies indicated that the hyaluronate fraction was readily labelled with $\mathrm{D}-\left[1-{ }^{14} \mathrm{C}\right] \mathrm{glucosamine}$ as precursor. The present work demonstrated that although
$N$-acetyl-D- $\left[1-{ }^{14} \mathrm{C}\right]$ glucosamine acted as a precursor in the biosynthesis of hyaluronate, the extent of its incorporation was less compared with that of D$\left[1{ }^{14} \mathrm{C}\right]$ glucosamine (Gallagher \& Kent, 1975). The hyaluronate fraction, purified from tracheal secretion after incubation of the explants with $N$-acetyl-D$\left[1-{ }^{14} \mathrm{C}\right]$ glucosamine as precursor, moved as a single zone on cellulose acetate electrophoresis, and acted as a substrate for hyaluronidase. The refractionated material on DEAE-cellulose chromatography had a specific radioactivity of $90 \mu \mathrm{Ci} / \mathrm{mmol}$ of uronic acid when labelled with $\mathrm{N}$-acetyl-D-[1-14 $\mathrm{C}]$ glucosamine $(8.28 \mu \mathrm{Ci}$ being originally present in $100 \mathrm{ml}$ of culture medium). Incubation with a mixture of glycosidases (hyaluronidase, $\beta$-glucuronidase and $N$-acetyl- $\beta$ hexosaminidase) released $54 \%$ of the labelled GlcNAc as free sugar, whereas the rest of the radioactivity remained in the oligomeric products. Similar observations on the hydrolysis of hyaluronate by these glycosidases had been made by Hayashi (1977). Despite extensive refractionation, monosaccharide analysis on g.l.c. showed that other sugars, notably galactose and mannose, were present in the tracheal hyaluronate preparation either arising from some impurity or as a part of some more complex structure with which hyaluronate is associated.

Labelling of the hyaluronate fraction with $\mathrm{D}-\left[1-{ }^{14} \mathrm{C}\right]-$ galactose has been reported previously (Gallagher \& Kent, 1975). Some recent exploratory doublelabelling experiments (performed by Ms. Caroline Anderson in this laboratory), however, showed that the hyaluronate component could be labelled with both $\mathrm{D}-\left[1-{ }^{14} \mathrm{C}\right] \mathrm{gluc}$ osamine and $\mathrm{L}-\left[\mathrm{U}-{ }^{3} \mathrm{H}\right]$ leucine, but not with $\mathrm{L}-\left[{ }^{3} \mathrm{H}\right]$ fucose and ${ }^{35} \mathrm{SO}_{4}{ }^{2-}$, when both the last two compounds were present simultaneously. The possibility exists therefore that the hyaluronate so obtained may indeed exist in some complex form with protein and the matter remains to be investigated. The results are similar to those of Stoolmiller \& Dorfman (1970) in which hyaluronate from culture 
fluids of Group A streptococci (papain-digested, chromatographically separated and purified by precipitation with cetylpyridinium chloride) contained about $2 \mu \mathrm{mol}$ of amino acids, including leucine, per $1000 \mu \mathrm{mol}$ of glucosamine. Unlike chondroitin sulphate, the biosynthesis of hyaluronate is not apparently sensitive to puromycin or chloramphenicol and thus is not thought to require essential peptide chains (Stoolmiller \& Dorfman, 1970).

Detailed comparison of the effect of fluorine present as the fluoroacetyl side group attached to glucosamine was made possible by the synthesis (Dwek et al., 1971) of $N$-fluoroacetyl-D- $\left[1-{ }^{14} \mathrm{C}\right]-$ glucosamine and $N$-fluoro $\left[{ }^{3} \mathrm{H}\right]$ acetyl-D-glucosamine in highly purified form. Both fluoro-analogues provided metabolic sources of labelled GlcNAc for all the soluble secreted protein-polysaccharide com-

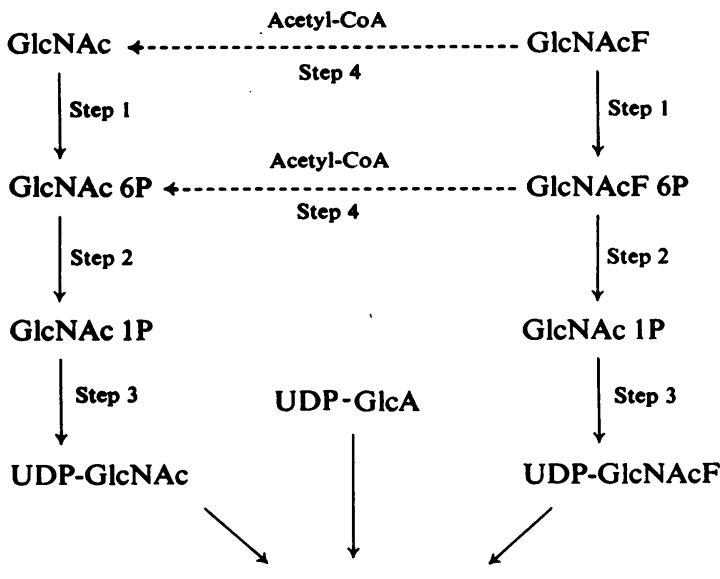

Acetylhyaluronate or

fluoroacetylhyaluronate Step 5

Oligosaccharide
GlcA-GlcNAc
GlcA-GlcNAcF
GlcNAc
GlcNAcF
GlcA

Scheme 1. Competitive metabolism of GlcNAc and GlcNAcF in hyaluronate biosynthesis

Abbreviations: GlcNAc 6P, $N$-acetylglucosamine 6phosphate; GlcNAc 1P, $N$-acetylglucosamine 1phosphate; UDP-GICNAc, uridine 5'-diphosphate $N$-acetylglucosamine; UDP-GlcA, uridine $5^{\prime}$-diphosphate glucuronic acid. GlcNAcF 6P, GlcNAcF 1P and UDP-GlcNAcF are the corresponding fluoroanalogues of GlcNAc 6P, GlcNAc 1P and UDPGlcNAc respectively. plexes, and hyaluronate, synthesized by rabbit tracheal explants. The possible metabolic pathway involved in the incorporation of the fluoro-analogues is summarized in Scheme 1. This Scheme, at present, is hypothetical and requires further data on the comparative kinetics of incorporation of GlcNAc and GlcNAcF into hyaluronate and on the effect of GlcNAcF on the incorporation of GlcNAc into hyaluronate, and vice versa, to clearly understand the competition between the two sugars during their incorporation into hyaluronate. The data on incorporation indicate that either by transport or by enzymic specificity, GlcNAc was utilized to a greater extent than the fluoro-analogues (Tables 2 and 3 ) and it was considered that identical initial enzymes were involved (Scheme 1, steps 1, 2 and 3). In attempts to increase the extent of labelling by prolonged incubation of tissue with these metabolites, it was found that enhanced labelling of hyaluronate resulted with both the GlcNAc and its fluoro-analogues up to $144 \mathrm{~h}$ of incubation with a concurrent decrease in the incorporation of the labelled material into the accompanying neutral and acidic secreted-glycoprotein fractions. The striking differences in the hyaluronate labelling arising from ${ }^{14} \mathrm{C}$ - and ${ }^{3} \mathrm{H}$-labelled GlcNAcF (Table 5) indicated strongly the possibility of partial loss or replacement of the side-chain acyl group (Tables 2 and 5) at any of the sugar phosphate intermediary states (Scheme 1, step 4). Further evidence on this point was obtained by study of the products of hydrolysis of the hyaluronates labelled with the two labelled fluoro-sugars followed by the action of the mixture of glycosidases. With ${ }^{14} \mathrm{C}$-labelled GlcNAcF as a metabolite, the action of mixed glycosidases (for $48 \mathrm{~h}$ ) as before resulted in recovery of $11.9 \%$ of the radioactivity in the form of free fluoro-sugar separated and identified chromatographically. This value decreased to $5.9 \%$ on prolonged glycosidase action with a corresponding increase in the labelling of the oligomeric component, thus clearly indicating the occurrence of some transglycosidation reaction. In addition, however, $25.1 \%$ of the ${ }^{14} \mathrm{C}$ radioactivity was present as GlcNAc, showing that some sidechain displacement must have occurred. The remaining radioactive isotope $(63.0 \%)$ was present in the oligomeric material, substantially greater than that found $(50 \%)$ for fluorine-free hyaluronate. Similarly with ${ }^{3} \mathrm{H}$-labelled metabolite, $11.2 \%$ of the radioactivity could be recovered after mixed-glycosidase degradation (for $24 \mathrm{~h}$ ) and chromatographically identified as the GlcNAcF (Table 6). The major part of the ${ }^{3} \mathrm{H}$ radioactivity remained in oligomeric products, and somewhat more extensive chromatography (Table 7) enabled comparison to be made of the glycosidase-degradation products.

The presence of fluoroacetylglucosaminyl residues in hyaluronate, which the evidence established, also appeared to lead to greater stability towards hyalur-

Vol. 182 
onidase degradation, compared with fluorine-free hyaluronate. This was further supported by the considerably greater yield under given conditions of enzymic hydrolysis of GlcNAc from normal hyaluronate than from that in which fluoroacetylglucosaminyl residues were present. Yamamoto (1973) showed that $p$-nitrophenyl 2-deoxy-2-fluoroacetamido- $\beta$-D-glycopyranoside was hydrolysed by purified $N$-acetyl- $\beta$-hexosaminidase at $65 \%$ of the rate found for the unsubstituted derivative, further supporting the constraining effect exerted by fluorine in this structural position on the enzymic hydrolysis of the substituted glycoside.

It is tempting to suggest that the accumulation of labelled GlcNAcF residues in the glycosidaseresistant oligosaccharide arises from enhanced resistance to hydrolysis of bonds between fluoroacetylhyalobiuronyl sequences in the polymer, compared with more susceptible fluorine-free regions. In a review, Muir \& Hardingham (1975) draw attention to the powerful structural effect that the acetamido groups of hyaluronate possess and it is reasonable to suppose that introductions of fluorine atoms at such points will markedly enhance the bonding capacity of sites.

It is concluded that GIcNAcF is utilized by tracheal cells in a manner closely similar to GIcNAc, that it is converted into the corresponding UDP-nucleotide precursor (Schultz \& Mora, 1975) and thence is incorporated into hyaluronate from which it can be recovered by enzymic degradation. The latter step is considered to be essential to the argument, especially in view of the metabolic transformations that the fluoro-analogue may undergo. In the course of these reactions, some enzymic de- $N$-acylation must be inferred, fluoroacetyl substituents being replaced by acetyl groups.

Since the primary aim of the present study was to see whether or not GlcNAcF was incorporated into hyaluronate, the effects of these fluoro-sugars on the general metabolism of the tracheal epithelial cells were not investigated. Although information on the protein-synthetic activity of the tracheal epithelial cells in the presence and absence of fluoro-sugars would have been of advantage in the analysis of the incorporation of the two sugars, it did not fall within the scope of the present investigation. However, the present findings that GlcNAcF was incorporated into hyaluronate would indicate that these fluorosugars did not have a deleterious effect on at least some of the biosynthetic pathways of the cells. Secondly the light-microscopic observations that the epithelium of the tracheal explants incubated with GlcNAcF for $96 \mathrm{~h}$ still exhibited vigorous ciliary motion would suggest that the presence of fluorosugars did not affect the general physiological behaviour of the cells.

We thank the Ministry of Defence and the Wellcome Foundation for support, the Science Research Council for a Training Award (to D. J. W.) and Mrs B. Chorley and Mrs. S. Jobling for their help.

\section{References}

Barnett, J. E. G. (1972) Carbon-Fluorine Compounds; CIBA Found. Symp. pp. 95-110, Elsevier/Excerpta Medica, Amsterdam

Bernacki, R. J., Sharma, M., Porter, N. K., Rustum, Y., Paul, B. \& Korytnyk, W. (1977) J. Supermol. Struct. 7, 235-250

Butchard, C. G., Dwek, R. A., Kent, P. W., Williams, R. J. P. \& Xavier A. V. (1972) Eur. J. Biochem. 27, 548-553

Clamp, J. R., Bhattie, T. \& Chambers, R. E. (1971) Methods Biochem. Anal. 19, 229-234

Daniels, P. F. (1972) Ph.D. thesis, Oxford University

Dwek, R. A., Kent, P. W. \& Xavier, A. V. (1971) Eur. J. Biochem. 23, 343-348

Foster, A. B. \& Westwood, J. H. (1973) Pure Appl. Chem. $35,147-168$

Gallagher, J. T. \& Kent, P. W. (1975) Biochem. J. 148, 187-196

Hayashi (1977) J. Biochem. (Tokyo) 82, 1287-1295

Kent, P. W. (1972) Carbon-Fluorine Compounds; CIBA Found. Symp. pp. 169-213, Elsevier/Excerpta Medica, Amsterdam

Kent, P. W. \& Mora, P. T. (1973) in Membrane Mediated Information (Kent, P. W., ed.), vol. 1. pp. 129-137, Medical \& Technical Publishers, Lancaster

Kent, P. W. \& Winterbourne, D. J. (1977) Biochem. Soc. Trans. 5, 439-440

Kent, P. W. \& Wright, J. R. (1972) Carbohydr. Res. 22, 193-200

Muir, H. M. \& Hardingham T. E. (1975) in Biochemistry of Carbohydrates (Whelan, W. J., ed.), pp. 153-222, Butterworths, London

Schmidt, M. F. G., Schwarz, R. T. \& Ludwig, H. (1976) J. Virol. 18, 819-823

Schmidt, M. F. G., Biely, P., Kraty, Z. \& Schwarz, R. T. (1978) Eur. J. Biochem. 87, 55-68

Schultz, A. M. \& Mora, P. T. (1975) Carbohydr. Res. 40, 119-127

Stoolmiller, A. C. \& Dorfman, A. (1970) Exposes Annuels de Biochemie Medicale ser 30, 65-78.

Taylor, N. F. (1972) Carbon-Fluorine Compounds; CIBA Found. Symp. pp. 215-235, Elsevier/Excerpta Medica, Amsterdam

Winterbourne, D. J., Butchard, G. C. \& Kent, P. W. (1979) Biochem. Biophys. Res. Commun. 87, 989-992

Yamamoto, K. (1973) J. Biochem. (Tokyo) 73, 749-753 